\title{
CIC/DUX4 Fusion Gene
}

National Cancer Institute

\section{Source}

National Cancer Institute. CICIDUX4 Fusion Gene. NCI Thesaurus. Code C139663.

A fusion gene that results from a chromosomal translocation $\mathrm{t}(4 ; 19)(q 35 ; \mathrm{q} 13)$ which fuses exon 20 of the $\mathrm{CIC}$ gene to exon 1 of the DUX4 gene. This fusion is associated with soft tissue sarcoma. 